\title{
Whatever happened to Work: from the centrality of shoes, ships and sealing-wax to the problems posed by flying pigs ${ }^{12}$
}

\author{
¿Qué pasó con el trabajo?: de la \\ centralidad de los zapatos, barcos y lacre \\ a los problemas planteados por los cerdos \\ volando \\ Peter Spink
}

Escola de Administração de Empresas de São Paulo, Fundação Getulio Vargas

peter.spink@fgv.br

\begin{abstract}
During their entire disciplinary lives, psychology and social psychology have treated work as a naturalized fact and an inevitable part of human existence. Whilst themes such as working conditions, decent work, work and subjectivity, work and vocation, guidance and careers may be discussed in a critical manner, the overall centrality of the work discourse is left untouched. In this essay it is argued that the multiple forms, possibilities, contradictions and restrictions present in contemporary economic relations are pointing to the weakening, or even fragmentation, of the articulating role of work and in third world countries like Brazil, where the western model of salaried wage employment was never extensive to more than a part of the population, this process becomes doubly complicated. In these circumstances it is important to seek a different starting point for the social psychological discussion of economic activity, which can give greater visibility to the multiple ways in which people "get by" in order to keep their homes together, sustain households and develop family collectives.
\end{abstract}

Keywords: Work; Fragmentation; Livelihoods; Exclusion

\section{Resumen}

Durante toda su vida disciplinaria, la psicología y la psicología social han tratado el trabajo como un hecho naturalizado y una parte inevitable de la existencia humana. Mientras que temas como las condiciones de trabajo, trabajo digno, trabajo y la subjetividad, trabajo y vocación, orientación vocacional pueden ser discutidos de una manera crítica, la centralidad general del discurso del trabajo ha permanecido intacta. En este ensayo se argumenta que las múltiples formas, posibilidades, contradicciones y restricciones presentes en las relaciones económicas actuales apuntan al debilitamiento, o incluso fragmentación, de la función articulatoria del trabajo y en los países del tercer mundo como Brasil, donde el modelo occidental del empleo asalariado nunca fue extensiva más que a una parte de la población, este proceso se vuelve doblemente complicado. En estas circunstancias, es importante buscar otro punto de partida para la discusión de la psicología social sobre la actividad económica, que pueda dar mayor visibilidad a las múltiples formas en que las personas "salen del paso" con el fin de mantener sus hogares y el desarrollar colectivos familiares.

Palabras clave: Trabajo; Fragmentación; Medios de subsistencia; Exclusión

\footnotetext{
1 "The time has come," the Walrus said, "to talk of many things: Of shoes --and ships--and sealing-wax--of cabbages--and kings--And why the sea is boiling hot--And whether pigs have wings." (Through the Looking-Glass and What Alice Found There. Lewis Carroll, 1872/2011, chap. 4.).

${ }^{2}$ Versión en español en: http://psicologiasocial.uab.es/athenea/index.php/atheneaDigital/article/view/955/603
} 
We need not go far in everyday life before meeting some kind of comment, newspaper article, advertisement or other media related product that seeks to remind us of the centrality of work to human existence and identity. For example, the question "what do you want to be when you grow up", which can be found from magazine articles, university advertisements to inter-generational conversations, is rarely answered - at least within western influenced cultures - by expressions such as "wise", "independent", "mature", "older", or "an active member of the community". The point here is not whether the implicit centrality is ontological to the human species or ideological (as Anthony, 1977, well argued) but with the pragmatic recognition that whether we like it or not its implications are both ubiquitous and by no means neutral.

Modernity - the long historical period of which we are both a social product and an active part - continues to be a complex and dynamic process of transformations, revolutions and contradictions in practice, politics and thought, which is far less stable than we think, especially in the third world (Spink, 2009a) and, in the case of modes of production, still in conflict. Karl Polanyi in his classic text (1944) argued that the rise of the $19^{\text {th }}$ century Market Society is a product of both a market economy and a nation-state and in the process the relation of the economic to the social becomes inverted. Instead of an economy that is embedded in social relations, social relations became embedded in the economy. In England, his main focus, this would require the repeal by the nation-state of local parish level social and community obligations that, despite their difficulties, were at least minimum guarantees of support. Whilst the rise of economic relations as an articulator of contemporary life would never become complete (Habermas, 1984; Thompson, 1993) there is no denying their discursive impact on late modernity's social imaginary.

This can be seen, for example, in the discussion on the contemporary characteristics of work in traditional and advanced capitalism (Antunes, 2009; Sennet, 1998), where work, employment, subjectivity and other terms are combined negatively and the struggle for "decent work" seem more and more distant. Certainly these and other excellent analyses, such as Nardi (2006) on the social consequences of work transformation and the demise of work society or Castel (1997) on the increasing vulnerability brought about by economic changes in Europe, represent important lines of argument and raise very real issues and concerns. At the same time, it is possible to find business enterprises that are considered good places to work, that follow the recommendations of the Internatonal Labor Office, that offer long term employment and a certain dignity and space for creativity. They may be a minority, but they can be found within the same economic arenas as global capitalism's sweatshop supply chains.

The problem with these arguments and counter arguments is not whether one or the other is "wrong" or "right"; it is that together their "noisy and domineering" presence has served to hide some very different approaches to economic and social relations which have remained - almost completely - over the horizon and out of sight of the reports, studies, documents and academic discussions about the world of work. What about, for example, the many small alternative organizations and collectives that seek ways of linking with their local economies that they consider more substantive, horizontal and collective. A significant number of these position themselves within the rules and institutions of the legal economy, abiding by labor and tax laws, complying with local edicts on health and safety; but an equally significant number do not, or at least do so in varying degrees. Leaving a trail of materialities, they are an ever present part of everyday life along with the millions of small businesses for whom life is not about becoming a big business or about elaborating entrepeneurial strategies for market dominance rather, on the contrary, it is about continuity and quality of products, services and social relationships; about "making ends meet" and "keeping my customers happy". But we know very little of what informs them or really 
how to enter into effective conversation; for our discursive starting point is that of the "noisy and domineering" and within this the assumption of the shared centrality of something we call work and which we assume as obvious. But are we talking about the same things?

\section{Work and Employment in Brazil}

The choice of Brazil as a background for this paper has a number of advantages, one of which is familiarity and access to the necessary information. Another is that it is a case in which certain contradictions are very aparent; whereas they may be less so in the more developed countries. It is neither a developed country, nor an underdeveloped country; it is a liberal democracy yet its public policy arena is highly questionable. Social rights are discursively present in, for example, its universal health system yet basic civil rights are often ignored. At the local level it has a number of highly innovative experiences in direct democracy and more open public management (Avritzer, 2009; Farah and Spink, 2008) yet has continued to maintain a high degree of racial inequality and is one of the world's most unequal countries in terms of income distribution. It has pockets of advanced technology alongside community based enterprises; subsistence farming alongside large scale agricultural and commodity based enterprises; some $90 \%$ of its local government units have less than 50,000 inhabitants yet many are huge territorially and it has some of the worlds largest conurbations crammed into less that $2 \%$ of its geographical area. It terms of mid-range theory, Brazil offers the possibility of dialogue in a number of different directions for it can be simultaneously characterized along a number of axis. It is neither typical nor atypical and may offer a point of contrast, comparison or similarity on a variety of issues.

This can be illustrated with a theme that has been constant in discussions of Brazilian labour statistics in recent years; that of the change in the structure of the labour market during the 1980s and 1990s from a setting in which some $60 \%$ of work was represented by formal employment and $40 \%$ by different kinds of informal relationship, to the opposite (60\% informal and $40 \%$ formal). This has eased back to around $50 / 50$ in recent years but the general pattern of significant informality remains. But, what is "informal" in statistical terms? Whilst, in the central western countries, people may be "self-employed" or may have a number of jobs, these will be always considered formal economic activities that require registration and are subject to taxation and to benefits. The economy is to an overwhelming extent "formal", "registered" and "visible". In these contexts, to refer to the informal economy is to refer to activities beyond the reach of the state, often illegal but certainly subject to fiscal and often legal sanctions.

Concern here is not with whether this is "good" or "bad" but with the social convention that it portrays: the aim of full employment. The idea of widespread employment, seen as registered and visible, including regulated self employment is not an old idea. Its centrality to the developed western world would only make itself present in the crisis of the 1930s and in the components of the welfare state as conceived in the 1942 British Beveridge report. As Hennessey puts it, these were: social security, health care, education, housing, social services and full employment without which: ".. as Beveridge himself had warned, the whole linked enterprise would be unstainable in terms both of consumption and the tax revenue needed to finace the extended state services and benefits" (Hennessey, 2007, p. 22). Thus full, registered and taxable employment is not just part of the model of the welfare state, it is its discursive keystone; holding the political and social enterprise together. In dramturgical language: enter stage left, Beveridge Man (who was indeed male). 
In the third world, and Brazil is no exception despite having achieved the status of a newly industrialized nation, there has never been anything similar. On the contrary, the $60 \%$ mark was probably the highest we ever got along the road to full (registered) employment and our high degree of informality, plus the generally low level of pay for formal work, is without doubt the reason why indirect taxes form the greatest part of our tax base. (It is generally agreed that indirect taxes applied to all goods and services place a higher tax burden on those with the lowest incomes). The social idea of full employment, understood in the formal sense with registered regular payments available for taxation was never a dominant characteristic of many intermediate economies such as Brazil. Rather, this has been a mix of slave and bonded labour, street sellers, artisans, day workers, migrant agricultural work, odd jobs amongst others as well as liberal professionals, industrial workers, commercial and service workers and public sector employees. Most of them continue to flow on together with the "informal" being the dominant practice, even though it is not the dominant discourse.

The introduction to a recent International Labour Office (ILO) discussion on the informal economy gives the following estimate: "The informal economy comprises half to three-quarters of all non-agricultural employment in developing countries" (ILO, 2010a p.1). Chen (2008) suggests something between 50$75 \%$ for non-agricultural economic activity (51\% in Latin America) and estimates that in Mexico, for example, this will be around $62 \%$ when agriculture is included. A similar estimate is given by Dennis Drechsler, Johannes Jütting and Theodora Xenogiani in a recent OECD (Organisation for Economic Cooperation \& Development) report:

The figures speak for themselves: the worldwide proportion of jobs that are performed outside of a country's formal structures governing taxes, workspace regulations and social protection schemes is high and occasionally even increasing. In developing countries the share may be more than half of all non-agricultural jobs and up to 90 percent if the agricultural sector is included - despite economic growth in many of these countries. The development in selected countries in South-East Asia and Latin America is telling in this respect: over the past 30 years growth was accompanied by increasing, not falling, informal employment $(2008$, p. 8).

With a focus on Latin America, José Nun (2000) argues that contrary to the generalized vision of the stable worker in a salaried society with the civil, political and social citizenship of the central capitalist countries:

...the increase in poverty and inequality and the lack of appropriate networks of social protection are leading to a consolidation of exclusive representative democracies with a minority of full citizens - which is the same as saying that present political regimes are scarcely democratic and scarcely representative. (2000, p. 25).

Carmelo Mesa-Lago (2008) uses data from CEPAL to examine the situation in a number of Latin American countries including Brazil. He suggests that explicitly informal work amongst the urban work force is around $40,5 \%$ rising when the urban "self-employed" are included to nearly $61 \%$. In rural areas, the number of "self employed" and non-remunerated family members is around $62,5 \%$. He comments: "the idea that development will eventually expand the formal sector and thus extend coverage is contradicted by factual evidence in Latin America over the last 25 years." (p. 85). In consequence: "Social 
Insurance therefore, must adopt to the transformation of the labour market, expanding coverage to informal and rural workers \& peasants, the poor and the elderly" (p. 85).

Similar arguments also apply to labour statistics. For example, the official Brazilian Institute for Geography and Statistics (IBGE) uses as its criterion for the unemployed: all those 15 years of age or more who are not in work but, in the week previous to the survey had effectively set out to find work or to open a business. The joint Trades Union Department of Statistical and Socio-economic Studies (DIEESE) uses a different definition that extends the search period to 30 days, but also includes those who haven't been looking for work in the last 30 days for lack of opportunities in the market but have done so in the last twelve months, and those who may have had some irregular work or helped parents but have tried to find work in recent months. As they argue, using traditional ideas of unemployment (no paid work) in a setting in which there are no broad support mechanisms for the unemployed and people have to "get by" somehow does not paint a very accurate picture. To look for work as Beveridge man, complete with State provided job centers and unemployment benefits is a very different scenario to that of the fragmented and precarious search and information setting in which functional illiteracy is still strong and people walk the city centers dressed in bill boards offering dubious and generic jobs. The difference in approaches is frequently around $80-90 \%$. Using as a basis the monthly survey of selected metropolitan regions, for August 2011 DIEESE posted an overall average of 11\% (DIEESE, 2011) for the principal metropolitan regions (varying from $8 \%-16 \%$ ) and the IBGE posted 6\% (IBGE, 2011).

But who were the "not unemployed"? Using the August 2011 estimates from DIEESE we find that of a population of 19,792,000 people that were economically occupied, 2.1 millions were in the public sector and 9.5 millions in the private sector with formal contracts (together totalling 59\%). Those in the private sector without registered contracts (1.8million), those working by themselves (3.3 million), domestic servants (1.4 millions) and a varied group (1.3 millions) of liberal professionals, family unsalaried workers, owners of family businesses make up the other forty-one percent. Hardly a homogeneous definition of a "workforce"or a "labour market". Combined, their average earnings were the equivalent to 565 euros (R\$ $1,360)$ nearly half the value of the DIEESE recommended minimum salary of 947 euros $(R \$ 2,278)$. Moving away from the metropolitan regions, from state to state and municipality to municipality the situation will change considerably with the presence of a factory, an open-cast mine or even local agreements for agricultural development. There will be many places when the only work available is very low paid in the local government or in daily paid farm labour at harvesting time. The importance of Brazil's Family Grant conditional cash transfer program (Fiszbein \& Schady, 2009) has demonstrated just how bad the situation is: in some parts of the country up to $90 \%$ of families will be dependent on the allowance to maintain minimum food levels and even then will still not be at the level of the official minimum salary of 226 euros ( $R \$ 545)$. Thus at any one time and across many spaces and places a very significant number of brazilians are trying very hard to go beyond survival and find ways of "getting by": finding ways of supplementing low incomes by growing food, finding odd jobs and developing all kinds of economic activities that are largely invisible to the formal statistics.

The validity of the "noisy and domineering" discourse, already shakey from the data, becomes even more fragile if we were to ask just how many of Beveridge Man's existing regulated posts require anything more that a very minimal set of capacities and abilities. According to the formal register, the great majority of job openings are for what in Brazil are termed unskilled or semi-skilled workers, a very clear reference to what can be expected. The switch from industry to services and the general de-skilling in general only serves to make this worse. They are, by and large, nominal jobs that count for statistical purposes but 
have hardly any implicit content and require hardly any skills, or at the most those skills that can be picked up in a day or two.

In contrast to the low demands of much formal work, the skills that are involved in "getting by" are extensive, often collective, produced out of school and transmitted in daily life. Drawing a parallel with the discussion by Clifford Geertz (1997) of local knowledge and common sense, these are not of an "inferior" kind, but an extensive, continuous and social process, made up of information, skills and aptitudes that are learned, stimulated, developed, transmitted, forgotten, remembered according to need and about which we know very little. However it is just this invisible and living library rather than the university business degree that is the only guarantee we have of the continuity and sustentability of social life. What is more, it is a library marked by the significant, if not majority, presence of women.

Until very recently, the vast majority if not the totality of articles, textbooks and studies that have been produced in the central western countries in the occupational, work and organizational area have taken as their focus the professional universe of formal employment in large military, private and public technobureaucracies (the ships and shoes and sealing wax of the essay title). There is no better place to follow this than the Annual Review of Psychology, which, before the development of electronic search mechanisms, was the principle means by which researchers in the central psychological nations kept themselves up to date. Present in the first volume (1950) as industrial psychology, it would continue in a variety of formats (personnel management, organizational psychology, psychology of men at work, personnel training, organizational development, engineering psychology) in a virtually uninterrupted manner well into the next century. A study of the different yearly chapters shows that throughout the next fifty years - the period in which the area would grow considerably in strength and importance - the focus of those producing the studies and writing the review chapters was with a very specific setting: the large work-as-employment hierarchical business, government and military bureaucracies. Rarely was this to be a cause for concern, even when Marvin Dunnette, commenting on Loren Baritz's (1960) critical account of the use of social science in US industry, stated that there is ".... degree of consensus that psychology and social science, instead of leading, are being led by business and management" (1962 p. 287).

Here is the introduction by Fiona Patterson for the special edition of the Journal of Occupational and Organizational Psychology (UK) for the centenary of the British Psychological Society in 2001:

The discipline of work psychology has accomplished a great deal in a short space of time, and is thriving. The field has undoubtedly evolved to perform a valuable role in society and in promoting the well-being of employees at work. This advancement can be attributed partially to the growing appreciation of the utility of work psychology in enhancing individual and organizational prosperity. The expertise of both academic and practitioner work psychologists has had an enormous influence in the way many organizations operate, ranging from multi-national commercial organizations, through to public-owned companies and the voluntary sector. (Patterson, 2001, p. 381).

\section{Getting by}

The alternative is clear: if we are going to be of any use in these chaotic times, we must start to collectively write a very different Annual Review chapter that begins by recognizing the hybrid, fragmented and multiple insertions and relationships that take place at the confluence of the social and 
the economical. We must move towards a better understanding about the many ways in which we sustain ourselves, make-do, get by, make ends meet and the many other similar expressions that are part of everyday life in both the dense urban settings of São Paulo, Barcelona and Mexico City and in the millions of other places both rural and urban of which nobody has ever heard.

Using the very simple idea of "getting by" or "finding something to do" is itself an important first step in inverting many of the existing relationships and notions, even inside the employer centered model of Beveridge Man. Contrary to what much work psychology has taught, most people pick up jobs in shops, offices and factories because they need the money in order to get by, find something to do, someone to talk to or make new friends. Part of the skills of "getting by" that are required in these settings have to do with surviving, keeping quiet, melting into the wall paper (or as female workers in São Paulo's open plan offices say - "looking like the scenery") and putting up with human resource and business psychologists talking about psychological contracts, commitments and involvement. Fortunately we do have studies mainly from sociologists and anthropologists - that confirm this side of factory life, largely ignored by Elton Mayo and his colleagues during the Hawthorne studies (Gillespie, 1991).

Getting by is not an area of work, a profession or even a market; it is people themselves who "get by", "make do" (in Portuguese the expression is: se virar - to turn this way and the other). The sociality of "getting by" is the materiality of millions of home based enterprises, odd jobs, alternative cooperatives and trading networks, the creation of local community currencies and "swop networks", cultural and musical activities, street statues and street services such as photography, document typing and letter writing, neighborhood commerce, small family businesses, in the transport and delivery of documents, materials, schoolchildren, people, furniture and hundreds of other objects, in recycling, in micro businesses moving in and out of informality and in millions of street food enterprises ranging from the coffee and home-made cake that can be found outside any building site in Brazil through to established mini-restaurants that have survived local government officials and become also "part of the scenery". "Getting by" is also people who add activities together in order to support their homes, adding taxi driving to police-work, waiting tables to lowly paid office jobs and bring food from home to sell in the office or the university. It is also the "taxi teachers" rushing from one school or university to another in order to give enough classes that they can "make ends meet" and thousands of other settings of which we know little because we either ignore them and push them under the mat or we look at them in terms of the "noisy and domineering" approach to employment-work.

Discussing "getting by" is not - contrary to what a number of business supported social organizations would propose - about some kind of new neo-liberal entrepreneurship or a burst of capitalist grass roots competence amongst those in low income settings or in situations of poverty. To begin with, "getting by" is what you have to do - it is not a career option! Second, the great majority of people do not seem to buy into the entrepreneurial approach to growth and seem to be content - in a positive way - to build up and maintain a life style that provides some kind of horizon and dignity, characteristics in constant social negotiation. Third, guaranteeing some kind of horizon and dignity can be a tremendous effort, as a few hours spent talking with cardboard, paper, plastic, bottle and tin can recyclers' cooperatives and associations, will soon show. The difficulties of access to economic resources, space, the battle for public legitimacy and social recognitions are a very different setting to the fantasy world of the "new entrepreneurship" perspective which is little more than a repetition of the "you can be a success if you only try" new thought movement at the end of the $19^{\text {th }}$ century (Bendix, 1956). 
"Getting by" can be about opportunities, but it is also about suggestions made collectively - "we don't have anybody to do this". But this is a socio-technical and not just social process. Networks of human and non-human actors, some of which like mobile street food equipment need to be invented and others supplied, social practices such as loans, protection, intermediaries of all types, forming social relations that may be built on solidarity or fear. "Getting by" is frequently contradictory, sitting between the pressures of the state (police, public officials and bribes) and the counter hegemonic local legitimacy provided by local communities to street traders of all kinds, as can be seen daily at many São Paulo bus stop shelters where it is possible to eat anything from biscuits to barbecues.

The practical horizons of "getting by" can vary immensely, from networks that cross borders to those micro-insertions that we have referred to elsewhere as the nano-economy (Spink, 2007, 2009b). Carrying out research on unemployment, Neiza Baptista (2005) spent many nights in the lines that form on the street outside the job centers in São Paulo, where people may arrive before midnight in order to guarantee a good place in the queue when the center opens at $8.00 \mathrm{am}$. On one of these nights she was chatting with a young girl who suddenly burst into tears as she started to tell the story of how she had been unable to get to the center because she didn't have the money necessary for the bus passes. She lived a long way from the regional administrative offices where the center was and she needed tickets to get there and back and also tickets to cross the city for interviews for job vacancies if any showed up. She asked her women neighbors to lend her some flour, milk, eggs and sugar with which she made several cakes. She then sold slices of cake at the bus stops until she had enough money to pay for the tickets and to give back the ingredients she had borrowed from her neighbors. In Brazil there are estimates of more than 35 million people who, through lack of money, cannot access what are often very precarious systems of public transport.

For social psychologists, it is worth recollecting at this point the short but highly insightful text by Kurt Lewin written under the title of "Ecological Psychology". In it he explores the way in which events are built up through the flow of action along networks of practices, both psychological and non-psychological, which he referred to as channels. Key in the channels are the gate-keeper moments in which flow could stop, be restricted, impose conditions or move on. His example was that of the reply to a simple question:

The question "why people eat what they eat", is rather complex, involving both cultural and psychological aspects (such as traditional foods and individual preferences caused by childhood experiences), as well as problems of transportation, availability of food in a particular area and economic considerations. Therefore the first step in a scientific analysis is the treatment of the problem of where and how the psychological and non psychological aspects intersect. This question can be answered in part by a "channel theory". Of paramount importance in this theory is that fact that once food is on the table, most of it is eaten by someone in the family. Therefore one would find the main answer to the question "why people eat what they eat" if one could answer the question, "how food comes to the table and why". (Lewin, 1952, p.174-175).

Urban agriculture, farmers' markets, local government interventions to guarantee the flow of food, supermarkets placing restrictions on local producers, the difficulty being faced by programs seeking to support and strengthen local producers in transforming raw material into commercial products, car boot sales and many other examples can be used to illustrate the channels and the gatekeepers, just in the area of food alone. But Lewin was not just talking about food, but about the complex way in which all 
events are put together and maintained and which today we would probably describe through the language of materialities and socialities, of actantes and of socio-technical networks (Law \& Mol 1995, Latour 2005).

Take, for example, those very key bits of the neighborhood nano-economy, the home based enterprises that use the only safe space available - the home - to create or sell products and services. The minishop in the kitchen window that opens to the street and which sells small portions of everyday products that people need either because they don't have the money, or the space, or the conditions (such as a refrigerator) to keep at home. The improvised shop in the entrance hall, or the garage, that sells second hand clothes; services such as sewing buttons, adjusting and repairing clothes or domestic equipment. All without approval, unregistered yet building economic possibilities through their contribution to the neighborhood and at times beyond. Adriana Agnes Rodrigues (2008) provides this description of Dona Fatima and her husband in São Paulo who turned to bread making at a key point in their lives when her husband was fired because of a back problem and the family for whom she worked as a domestic servant moved to a different part of the county:

I had an oven and a gas cylinder that we had bought at Christmas time to do the roast, so I thought - this is what we will use to make bread. I began with my brother's credit card - He leant me his credit card and I used it for a while to buy the ingredients I needed to make bread. We built a cart to carry the bread and my husband would go out on the street, from door to door, house by house, offering bread for sale. Sometimes he couldn't sell more than 10 loafs and he would come back with all the rest. The next day we would do it all over again because the loaves had to be fresh; nobody wants yesterday's bread. The next day we would do it all over again, take the money that came in, buy more ingredients, make twenty loaves and go out into the street again. We would keep knocking on doors, he would go outside the neighborhood in the day-time and I would go out at night here in the neighborhood where I am known. Six thirty in the evening I would go out and come back at eleven. For four years we did this, knock, knock, door to door; we had a program for each day to go to different neighborhoods. When we began we only made twenty loaves a day and now we are up to 60 big loaves and many different smaller loaves; on Friday we make over $150 \ldots$ (2008, p. 52-53).

In their conclusions to their studies on home based enterprises in Bolivia, India, Indonesia and South Africa, Graham Tipple, Justine Coulson and Peter Kellet (2002) comment that these are in general statistically invisible and their contribution to everyday life and to the national economies is ignored by public policy formulators who tend to have a more utopian model of suburban life. As John Friedmann (1992) pointed out: people are rarely alone as isolated social beings, they are usually to be found in households or in family and friendship networks. Family may be a social notion but households are both social and technical; they offer resources, shelter and a place to work and for this reason the home based enterprises are amongst the world's largest economic activity and the world's most invisible economic activity. Credit is a key aspect, as are equipment, skills, time and relationships including that between producer and client: "nobody wants yesterday's bread". However equally important, as Friedmann pointed out, these are all areas in which the State, theoretically, is present. Perhaps the local state helps by forgetting the existence of home based enterprises and not applying food production norms but does it help or hinder in other areas. The credit that Dona Fatima needed did not come from a micro-credit 
agency, on the contrary it came from a very common community resource - a friend or relative's credit card.

The idea of borrowing and lending credit cards to gain 30 days of free credit on the understanding that the loan will be paid back before the payment date, is not something that university trained financial specialists would ever think about, even though it is a common practice. Indeed for many of our academic colleagues, the proposal that they should devote their efforts to the world of "getting by" would be considered a hindrance to an academic career and a sure way to miss out on the great benefits provided by our disciplinary devotion to big techno-bureaucracies. It may seem like "flying pigs" to them - but that is the challenge we are facing and which little by little is being taken up.

\section{A challenge with a face}

If the size of the challenge that we face is not daunting enough in today's terms it will be even more so tomorrow. In Brazil, in addition to the some $50 \%$ of economic insertions that are part of "getting-by", annually some $1,500,000$ youngsters arrive at ages when they need to fend for themselves or contribute to their families and households. As there have been very few out of the last 10 years when the number of formal employment-work posts created has been higher than one million, we are in a situation where job creation within the traditional sense of the word neither reduces existing unemployment nor deals with new entrants. Young people are at the blunt of the labour market changes all over the world as an earlier ILO report for the $93^{\text {rd }}$ session of the International Labour Conference (2005) was already alerting:

The vast majority of the world's youth work in the informal economy. In Africa, 93 per cent of all new jobs and in Latin America almost all newly created jobs (for young labour market entrants) are in the informal economy. Young informal workers frequently work long hours with low wages, under poor and precarious working conditions, without access to social protection, freedom of association and collective bargaining. (ILO, 2005 p.4).

The situation, as we now know, has only worsened as a result of the recent economic breakdowns and in 2010, the ILO and the OECD was to point to a rise of unemployment amongst young people to some $34,1 \%$ in the central OECD countries and to the situation where the numbers of young people between 16 and 24 years of age in Spain and Italy who neither study nor work, had already passed 15\%. Elsewhere the ILO was already discussing the possibility of a "lost generation".

Young workers in the lower-income regions have been less obviously impacted by the crisis, at least as reflected in the most readily available measures such as unemployment. The reasons pointed out in this report are that most developing economies have a much smaller share of youth working in fixed establishments that might lay off workers - most workers are self-employed and engaged in informal sector activities - and because few countries have the social protection framework for offering unemployment benefits that can subsidize the job search. But this is not to say that youth in low-income countries have not been affected. The current crisis threatens to exacerbate the challenges of rampant (but difficult to quantify) decent work deficits in developing regions, adding to the number of working poor and slowing the rate of progress being made in recent years on poverty reduction, educational attainment, 
fertility and health, all the elements of human development that shape the current and future generation of young people. As more young people remain (or enter) in poverty over the course of the crisis, the hope of seeing a youth-driven push toward development in low-income countries remain stalled. It is fairly safe to argue, therefore, that the true "lost generation" of youth is the poor in developing regions. (ILO, 2010b p.1-2) .

What then are we to offer? Roll out the hopes for Beveridge Man yet again, or appeal to some human resources - labour economics -World Bank view of the importance of formal education and training for job procurement? Or can we summon the academic courage to turn away from the "noisy and domineering" discourse that continues to flow around work and social psychology and try to respond sincerely to what the evidence tends to show, that it is time to put something else in its place.

\section{Getting used to pigs with wings: understanding the non- formal}

So far I have used a variety of everyday expressions to refer to the immense universe of economic insertions that has been, for the most part, over the horizon and out of sight. Each country and language has its own; a clear reference to the existence of life outside employment-work. In Spain it is common to hear "garantizar las habas" or "buscarme la vida", references to getting involved in life and keeping the "beans" flowing in. Brazilians will refer to bread instead of beans, "ganha pão" and the English will be concerned with "getting by" or "keeping the wolf from the door".

An early attempt to characterize the differences was made during the 1970 s with the idea of informal work (Hart, 1973) used in reference to the developing world. Today there are a number of approaches to definitions that can be found in the literature. Drechsler et al, for the OECD, place their emphasis on legal registration and protection. For example:

Informal employment refers to Jobs or activities in the production and commercialization of legal goods and services that are un-registered by or hidden from the State, most importantly for tax, social security and labour law purposes. Due to its concealed nature, measuring informal employment is a huge and daunting task, but ignoring it is not an option; the informal sector" is of major economic and social importance in developing countries (Drechsler et al, 2008, p. 8).

Others seek to tease out some of its differences:

Broadly defined, the informal economy includes the self-employed in informal enterprises (i.e. small and unregulated) as well as the wage employed in formal jobs (i.e. unregulated and unprotected) in both urban and rural areas. So defined, informal labour markets encompass rural self-employment, both agricultural and non-agricultural, urban self-employment in manufacturing trade and services; and various forms of informal wage employment (including day labourers in construction and agriculture, industrial outworkers, and more). (Chen, 2008, p. 19). 
In the category of self employment, Chen includes employers themselves, own account workers and unpaid contributing family members (households) and informal wage employment includes: informal employees, casual or day labourers and industrial outworkers. Self-employment is perhaps the most common description that applies to Latin America, involving, she estimates, for $60 \%$ of all informal work. Self-employed is, however, an Anglo-Saxon expression, in Portuguese people would use "autonoma" (autonomous) or "por conta própria" (on my own account) meaning that the person looks after his or her self.

In both the English and Portuguese versions there is a nuance in the phrase that refers to both models at the same time: "self" and "employed" or "my" and "account". The person works for somebody (Beveridge man) but that somebody is themself! In the same way, Fields (2005) points out that in urban informal markets there is a sector which is occupied by those who for various reasons - including the transaction costs of formality - prefer to remain informal, even though they could in the right circumstances move sides. Hernando de Soto has pointed to the importance of legal mechanisms, including land titles, that enable people to leverage economic opportunities without which access to the advantages of the formal economy become impossible (de Soto, 2003). But there is also, as Fields continues, another sector which is composed of those who cannot survive without income generating activities yet can never access formal work.

If we also look more closely within the formal market, we will see that there is a significant sector that is formally registered yet whose productive practices, economic and social relations are in no way linked to the dominant models. Pérez Sainz (1998) in discussing the informal urban economy in Central America proposes the idea of "neo-informality" to refer to: "...those urban economic activities which, in a context of capitalistic modernisation of the periphery, are characterized by a simple division of labour in which the owners are directly involved in the process of generating goods and services". (1998, p. 161).

Thomas (1995) in discussing urban informal economic activities in mainly urban areas, distinguished between activities directly linked to subsistence (generated and consumed within the household), the urban informal sector, the irregular sector and the criminal sector. This last area of activity even though engaged in market related actions, has its focus on goods and services that are declared illegal. Between the other two, the distinction is a delicate one and depends on the context. Both are involved in market transactions with the former (informal) consisting of legal goods and services whose production and distribution is "quasi-legal"; for example street sellers of legitimate goods or street food producers. In the latter (irregular), sometimes referred to as the parallel or black market, there is an implicit legal contravention in relation to either the productive process (employment of informal labour) or components (for example illegal importation or generation of copies). However the boundaries can be quite fudged at times and certainly depend on negotiation between local moral orders. Bus drivers will allow street sellers onto the bus because customers may need water and sweets on a hot day when traffic is an a standstill; in places where import duties are high, arguments of "fairness" can quickly take the place of the more legalistic "right" and "wrong". In England, goods still "fall off the back of a lorry" (that is have no origin) and in downtown São Paulo a street vendor of illegally copied DVDs was heard to reply to a potential customer's question about their authenticity: "Good heavens no, these are not pirated, you can't trust the quality of pirate DVDs; mine are very good quality, they are just generic" (the expression generic borrows from the discursive imagery of generic medicines, which in Brazil have brought down considerably the cost of pharmaceutical based health and weakened the cartel of the drug companies). 
If we link the different proposals of Fields (2005), Pérez Sainz (1998) and Thomas (1995), we can develop an initial approximation with two versions of formality (understood as income generating activities within the registered economy, obeying legislation, recieving social protection and providing tax or insurance contributions) and two versions of what perhaps it is better to call non-formality in order to provide a more positive and independent perspective. Within the formal, one version would include the central area of formal work (manufacture, services, commerce, public and third sector) and the other the formal periphery of the formal sector (Pérez Sainz's "neo informal") with its various versions of consultants, service firms, cooperatives, associations, local commerce, micro-firms and many millions of small businesses.

On the non-formal side we could begin with the non-formal periphery comprising those income-generating activities that are voluntarily non-formal and at times irregular, subject to attempts at regularization and go on to the central area of non-formal activity where people have very little alternative outside of this sector and their presence will be almost permanent. It is just as much a way of life as is its counterpart on the formal side.

However, the model - formal centre, formal periphery, non-formal periphery, non-formal centre - should not be taken to imply any radical separation into types. These are four quadrants that are best seen horizontally rather than vertically, for there is no sense in talking about hierarchies, and their boundaries are open. The popular economy, for example, has its stronghold in the non-formal yet spreads across to the periphery of the formal. Equally, as Nicola Pratt (2006) recognized in her work on street enterprises (those that use the public spaces of streets and parks):

....in practice, very few "informal" economic activities are unregulated by the state. Informal enterprises are affected by state regulations regarding environment and highways amongst other things. Many street vendors and others working on the street obtain permits from the relevant authorities. (Pratt, 2006 p.38).

The importance of the model is to draw attention to the demographic fact that the first (formal centre) is certainly on a global scale smaller than the last (non-formal centre) and that the second and third (the two peripheries) are linked in an immense nomadic and hybrid territory of lateral movements that can also include parts of the first and last. Take for example, the street markets, another major source of income generating activity with both formally registered stands and "add-on" activities such as bag carriers, lemon sellers and the like that are tolerated by the traders themselves. Sato (2007) in her work on street markets points out that within the municipality of São Paulo there are some 900 street markets providing economic activities to at least 40,000 people and sustaining many more. One the one side, the market traders occupy a registered place in the street market, but at the same time will count on family members and carry out the majority of their transactions in cash. The state can be found everywhere, both through actions designed to support enterprises and actions designed to hinder autonomous action. In the same way, people may accept state restrictions or fight against them, either passively through bribery, or actively through various forms of countercultural action.

\section{Making visible the taken for granted}

The mixing of metaphors in the subtitle is conscious. For much of what we are talking about is not "invisible" in the physical sense; the socialities and materialities of the joint peripheries are very much part 
of our day to day, as are the activities of the non-formal centre. However they are largely "invisible" within psychology and social psychology - as well as a number of other disciplines - because these, as we have already pointed out, have basically been at the service of the "noisy and domineering". They are not, however, "invisible" to psychologists when these act as ordinary persons, they are just taken for granted. We are active participants in the linked peripheries when we say we don't need a receipt (nota fiscal), when we stop to talk to a street seller, or buy a bottle of cold water at the traffic light. But in general we don't pay attention in the same way that we might do when we see an office block, a factory, a supermarket or shopping centre. These are physically big, they have names that we read about in the papers and they appear in advertisements, so it is fairly natural to assume that the noisy and domineering are the "masculine" center of the universe: that is the way with materialities and socialities.

But, when we see a woman selling coffee and home made cake at the bus stop early in the morning, surrounded by office workers and domestic servants who had to get up at four o'clock in order to travel in from the outskirts of some of our immense metropolitan regions, we don't stop to think that she is a part of an immense world wide network of open access franchises called "street food". Equally we don't realize that this gigantic collective whose female and male members might not know each other but can certainly recognize each other, sustains directly millions of people and their families and supplies food daily to billions of people around the world (2.5 billion in a recent United Nations Food and Agricultural Organization estimate cited by the São Paulo based Instituto da Defesa do Consumidor, IDEC, 2008). Street activities, those that use the street as a space, can be found throughout the third world and it is often what distinguishes the global south from the north. In Cali Colombia, Ray Bromley (1997) suggested nine different categories of street based activity: retailing, transport of people and objects, services such as shoe shine, document typing, security services (night guards, car watchers), gambling (lottery tickets), recycling, prostitution, begging and petty theft. Street retailing is an art in itself, running from portable hand carried showcases, through specially constructed bicycles to miniature value chain networks. In Guatemala City, for example, I remember a street market for clothes in which one stall sold plain "generic" jeans of different types, her neighbour sold the identity patches of different top best-seller and high value brands, and his neighbour would sew them onto the jeans with a hand turned sewing machine. Marzia Grassi (2003) working with the mainly women traders in the street markets of Cape Verde, draws attention to the expression used to describe the traders: rabidantes, which means to get yourself out of a mess or to find a way through and is used to refer to someone who is very good at convincing others (rabida bô). The rabidantes move around a regional space that includes Brazil and Europe purchasing and carrying goods to support the local Cape Verde markets. In the "La Salada" market in metropolitan Buenos Aires, described as the largest informal market in Latin America with a weekly turnover of some ten million dollars and over fifteen thousand points of sale and 50,000 daily visitors, purchases can now be made with on line debit and credit card transactions. Throughout Brasil there has been a similar growth in large regional markets (usually overnight because of the heat) that serve as supply points for hundreds of micro sales outlets. Immense as they may be, these markets are also vulnerable to government pressure; in Luanda, Angola, what was described as the largest open-air market in Africa closed its doors when government decided that it had gone too far.

Shopping as an economic and social activity is not just about street markets. It is also about local commerce: all those different types of commercial and retail outlets and services whose basic sales strategy is to have their doors open for whoever might pass by. It includes, amongst others, shops, repair services and snack-bars. With the exception of the occasional chain store or franchise, these are 
generally family based enterprises: hairdressers, shoe repairs, building materials, dog food, beauty products, clothes and sweet-shops, bread shops, mini-markets, television, washing machine and kitchen equipment repairs, neighbourhood restaurants, as well as the thousands of micro-businesses that open directly on to the street run by woodworkers, metal-workers, car repair specialists and many others. Street level enterprises of these kinds are not only responsible for supporting hundreds of people and families but are also key in that most important - yet curiously fragile - of everyday experiences: collective cordiality. Collective cordiality is that odd social process present in everyday actions like "good morning what can I do for you?" - "I'm not quite sure what I need but I have this problem with my sink" or: "Do you have such and such?" - "No, but Dona Rosa does, just around the corner". These are questions that assume a sociability that goes beyond the simple commercial transaction of the shopping mall or supermarket chain and refers to skills, knowledge and a collective response to service provision. Thus it is expected that the owner of the building materials shop knows about sinks, because that is his trade. The person asking the question does not need to know what he wants, because he is an office worker and it is saturday morning - he is not a plumber. Dona Rosa is around the corner; she is also part of an invisible commercial network. The notion of cordiality is what keeps it all together and these different fragments in turn keep cordiality flowing, for cordiality as a social process is a product of cordial actions. It may not be easy, with traffic and robberies and the presence of local government inspectors keen to find something wrong but, fortunately, it manages to hold on. Unfortunately though, there is not a single vocational guidance psychologist at São Paulo's leading universities who would suggest that somebody should seek their future in this very ordinary neighborhood where people say good morning and put a chair outside their roll-up mini-businesses to enjoy the afternoon sun. These are just some of what Puplampu referred to as the "neglected professions" (2003).

\section{The "livelihoods" approach}

As I have argued so far - and illustrated through cases and examples - the inherited model of workemployment seems totally inadequate to deal with the current setting. Opening up the formal-informal divide is certainly a step forward but what other organizing concepts might also be useful in order to recenter the discussion? One of the expressions that have been in increasing use in the development studies arena is that of "livelihoods". Livelihood is difficult to translate and its closest synonym would be "means of support" or "meios de sustento" in Portuguese. (Translators tend to use "meios de vida").

Here is a definition of livelihood from Wallman's (1982) study of inner London households:

Livelihood is never just a matter of finding or making shelter, transacting money, getting food to put on the family table or to exchange on the market place. It is equally a matter of ownership and circulation of information, the management of skills and relationships, and the affirmation of personal significance - involving issues of self -esteem - and group identity. The tasks of meeting obligations, of security, identity and status, and organising time are as crucial to livelihood as bread and shelter. (1982, p.5).

Norman Long (2001) follows a similar line in his actor perspective approach:

Livelihood best expresses the idea of individuals and groups striving to make a living, attempting to meet their various consumption and economic necessities, coping with uncertainties, responding to new opportunities and choosing between different value 
positions... in many situations confederations of households and wide-ranging interpersonal networks embracing a variety of activities and crosscutting rural and urban contexts, as well as national frontiers, constitute the social fabric on which livelihoods and commodity flow are interwoven. (2001, p.55).

Seen in this way, livelihood enables us to reposition economic and social relations, for it applies openly to all sectors of society. When a wealthy family invests in their children's education with a view to guaranteeing access to certain opportunities, or a young medical doctor borrows funds in order to spend a period as a resident in a specialist hospital, they are also engaged in livelihood building. The difference is in the access that these may have and the lack of access that others may have. John Friedmann posed this well when listing what he referred to as the eight bases of social power, that which is available to a household economy in the production of its life and livelihood (1992). These can be expressed in terms of access: access to a defensible and secure territorial base; surplus time; knowledge and skills; appropriate information; social organization; social networks; instruments of work and livelihood; and financial resources. In all these areas the state is potentially present, but it is present in an unequal manner. All of these items would be taken for granted aspects of daily life by those who write $99 \%$ of the articles on work and employment. But for the vast majority of the population in the third world, these are far from granted; indeed they are very difficult to come by and often actively denied.

Livelihood as an articulating expression gained academic momentum in part as a result of various international conferences and documents including the 1987 Bruntland Report, the 1992 United Nations Conference on Environment and Development and major investments by a number of bi-lateral development organizations including the UK's Department for International Development (DFID) and the Swedish International Development Agency (SIDA) (c.f. Carney 2002; Krantz 2001). Along the way it has gained a qualifier, "sustainable livelihoods", which -despite its attraction - creates a number of issues.

On the positive side is the investment by many authors in making more visible and discussable ways of going about income generation that would otherwise remain within the blanket expression of the "informal" economy. On the less positive side is the very clear association of "livelihoods" with poverty reduction and therefore with the poor (for example: Rakodi and Lloyd Jones, 2002; Brown 2006, Helmore and Singh 2001). The sustainable livelihoods approach was initially focused on rural sustainability, where questions of crisis and natural disasters were very present, and later migrated to the urban arena. The result, within the language of development economics, was the somewhat arid definition originally coined by Robert Chambers and Gordon Conway (1992):

A livelihood comprises the capabilities, assets (stores, resources, claims and access) and activities required for a means of living: a livelihood is sustainable which can cope with and recover from stress and shocks, maintain or enhance its capabilities and assets, and provide sustainable livelihood opportunities for the next generation; and which contributes net benefits to other livelihoods at the local and global levels and in the short and long term (1992, p. 7).

It is here that the over-association of "sustainable livelihoods" with "poverty reduction" becomes complicated. For it is one thing to argue that we are facing very unequal distributions and restrictions to key social goods and that as a result the livelihoods of some are far less secure than for others. But it is something very different to fall into the trap of suggesting that "sustainable livelihoods" is a good way of 
thinking about policies for those in poverty. Indeed, why is it the "poor" that always have to behave sustainably? As Robert Castel commented in his discussion of the over-use of the term exclusion (1997), it is very easy to fall into the mistake of assuming that people somehow got themselves excluded and, in doing so, ignore the economic and social processes that have placed and maintain a huge percentage of our populations in highly vulnerable settings.

One of the so-called weaknesses of the social sciences is our practice of using terms that are part of our language; we have no formulae nor do we create abstract expressions. At the same time this can be seen as part of our resolve to place ourselves firmly in everyday life. Livelihood is one of these examples; it helps us to advance but at the same time it creates difficulties that we must be careful to avoid. Contrary to many of our colleagues in the development community, we must argue that livelihood is not something that refers to those in poverty settings but, on the contrary, it is an expression that intuitively most of us in Latin America and the rest of the third world understand.. For what we have in common is that we never had Beveridge Man; our States were never welfare and most of us learned that we had to get on and survive somehow. This is perhaps the very positive and timely contribution - strange though it may seem - that we bring to contemporary affairs and to the street level discussions and protests that are sweeping Europe.

\section{From Beveridge man to BIG woman}

Beveridge Man as an icon of the welfare state represented a set of public policies that were certainly effective in their time and place. Unfortunately, as we have argued, the basic tenets were never practicable in the vast majority of third world countries and are increasingly impracticable elsewhere. To aim for Beveridge Man even in a non-gendered manner, is to increasingly divide rather than bring together. What then can we offer as an alternative in addition to the idea of livelihoods and a broader approach to the study of "getting by"?

One part of the answer will, without doubt, emerge from the various experiments - some local and others national - with basic income guarantees (BIG) or, to use the Latin American expression "basic citizen income". The very simple, yet radical, idea is that on reaching a certain age, every person would have the right to a minimum income that would be sufficient for daily needs (van Parijs, 1992). The idea might sound "insane" but initial experiences have been in place at the municipal level in Brazil for at least 20 years (Suplicy, 2006) and are also present in different parts of Africa. At the national level, Brazil's family grant scheme, although couched in the language of the conditional cash transfer, has showed how it is possible to extend the approach at a nationwide level. The monetary values have not been high but the results have been quite significant in terms of effective emancipation and empowerment. Moving towards citizen incomes is not a replacement for public services, but their complement. Public health, education and welfare resources are not commodities but knowledges (Spink, 2001) that we have put a lot of collective effort into building up and which we need to maintain. Guaranteeing that every person on reaching a certain age will be able to draw on a minimum income both adds on to and radically revises the idea of citizenship as a collective concept. It might not provide the famous "level playing field" but it at least would provide the great majority of people, both men and, most importantly, women (Pateman, 2004) with a different starting point for answering the question: "what do you want to be when you grow up?". 


\section{Referencias}

Anthony, P .D. (1977).The ideology of work. London: Tavistock Publications.

Antunes, Ricardo (2009). Adeus ao trabalho? São Paulo: Cortez Editora.

Avritzer, Leonardo (2009). Participatory Institutions in Democratic Brazil. Baltimore Maryland: Johns Hopkins University Press.

Baptista, Neiza Cristina Santos (2005). Pegando Fila... contando um pouco da cotidianidade do trabalhador desempregado na cidade de São Paulo. Unpublished master's thesis, Pontifícia Universidade Católica de São Paulo.

Baritz, Loren (1960). The Servants of Power: a history of the use of social science in American industry. Middleton Conn.: Wesleyan University Press.

Bendix, Reinhard (1956). Work and Authority in Industry: ideologies of management in the course of industrialization. Berkeley, Cal.: University of California Press.

Bromley, Ray (1997). Working on the streets of Cali, Colombia: survuval strategy, necessity or unavoidable evil? In Josef Gugler (Ed.), Cities in the developing World: Issues, Theory and Policy (pp. 124-138). Oxford: Oxford University Press.

Brown, Alison (2006). Contested Space: Street Trading, Public space and Livelihoods in Developing Cities. Rugby: Intermediate Technology Publications.

Carney, Diana (2002). Sustainable Livelihoods Approaches: Progress and Possibilities for Change. London: Department for International Development (DFID)

Carroll, Lewis (1872/2011) Alice's Adventures in Wonderland \& Through the Looking Glass. Oxford: Oxford University Press.

Castel, Robert (1997). As Armadilhas da exclusão. In Robert Castel, Luiz Eduardo Wanderley \& Mariangela Belfiore-Wanderley (Eds.), Desigualdade e a Questão Social (p.17-50). São Paulo: EDUC.

Chambers, Robert \& Conway, Gordon (1992). Sustainable Rural Livelihoods: Practical Concepts for the $21^{\text {st }}$ Century. Brighton: University of Sussex, Institute for Development Studies.

Chen, Martha (2008). Informality and Social Protection: theories and realities. IDS Bulletin, 39(2), 18-27.

DIEESE (2011). Mercado de Trabalho Metropolitano (Agosto 2011). Accessed in 08/10/2011, from http://www.dieese.org.br/ped/metropolitana/ped_metropolitana0811.pdf

Drechsler, Dennis; Jütting, Johannes \& Xenogiani, Theodora (2008, december) Is Informal Normal? Towards more and better jobs. Poverty in Focus, 16, 8-9.

Dunnette, Marvin (1962) Personnel Management. Annual Review of Psychology, 13, 285-314. 
Farah, Marta Ferreira Santos \& Spink, Peter (2008). Subnacional Government Innovation in a Comparative Perspectiva: Brazil. In Sandford Borins (Ed.), Innovations in Government: research, recognition and replication (pp. 71-92). Washington DC: The Brookings Institution.

Fields, Gary (2005). A guide to multisector labour market models. World Bank Social Protection Discussion Paper No. 0505. Washington, D.C. : The World Bank.

Fiszbein, Ariel \& Shady, Norbert (2009). Conditional cash transfers: reducing present and future poverty. Washington D.C.: The World Bank.

Friedmann, John (1992). Empowerment: the politics of alternative development. Oxford: Blackwell.

Geertz, Clifford (1997). O Saber Local: novos ensaios em antropologia interpretativa. Petrópolis, RJ: Editora Vozes.

Gillespie, Richard (1991). Manufacturing Knowledge: a history of the Hawthorne experiments. Cambridge: Cambridge University Press.

Grassi, Marzia (2003). Rabidantes: Comêrcio Espontâneo Transnacional em Cabo Verde. Lisboa: Imprensa de Ciências Sociais.

Habermas, Jurgen. (1984). Theory of Communicative Action. Boston: Beacon Press.

Hart, Keith (1973). Informal income opportunities and urban employment in Ghana. Journal of Modern African Studies, 11, 61-89.

Helmore Kristin \& Singh, Naresh (2001). Sustainable Livelihoods: building on the wealth of the poor. Bloomfield CT: Kumarian Press.

Hennessey, Peter (2007). Having it so good: Britain in the fifties. London: Penguin Books.

IBGE

accessed

in

08/10/2011,

from http://www.ibge.gov.br/home/estatistica/indicadores/trabalhoerendimento/pme_nova/default.sht $\underline{m}$

IDEC (2008, Novembro). Comida de Rua. Revista do IDEC, 32-35

ILO (2005). Youth Pathways to decent work. Report for the $93^{\text {rd }}$ Session of the International Labour Conference. Geneva: Author.

ILO (2010a). accessed in 22/10/201, from http://www.ilo.org/global/topics/employmentpromotion/informal-economy/lang--en/index.htm

ILO (2010b) Global Employment Trends for Youth, August. Geneva: Author.

Krantz, Lasse (2001). The Sustainable Livelihood Approach to Poverty Reduction. An Introduction. Stockholm: Swedish International Development Cooperation Agency (SIDA).

Latour, Bruno (2005). Reassembling the Social: an introduction to Actor-Network-Theory. Oxford: Oxford University Press. 
Law, John \& Mol, Annemarie (1995). Notes on materiality and sociality. The Sociological Review, 43(2), 274-294.

Lewin, Kurt (1952). Field Theory in Social Science. London: Tavistock Publications.

Long, Norman (2001). Development Sociology: actor perspectives. London: Routledge.

Mesa-Lago, Carmelo (2008). Informal Employment and Pension and Healthcare coverage by Social Insurance in Latin America. IDS Bulletin, 39(2), 79-86.

Nardi, Henrique C. (2006). Ética, Trabalho e Subjetividade: trajetórias de vida no contexto das transformações do capitalismo contemporâneo. Porto Alegre: Editora da Universidade Federal de Rio Grande do Sul.

Nun, José (2000). The end of work and the "marginal mass" thesis. Latin American Perspectives, 27(1), 6-32.

Pateman, Carole (2004, march). Democratizing Citizenship: Some advantages of a Basic Income Grant. Politics and Society. 89-105.

Patterson, Fiona (2001). Developments in Work Psychology: Emerging Issues and Future trends. Journal of Occupational and Organizational Psychology, 74(4), 381-390

van Parijs, Philippe (Ed.) (1992). Arguing for Basic Income: Ethical Foundations for a Radical Reform. London: Verso

Pérez Sainz, Juan Pablo (1998). The new faces of informality in Central America. Journal of Latin American Studies. 30, 157-179.

Polanyi, Karl (1944). The Great Transformation. Boston: Beacon Press.

Pratt, Nicola (2006). Informal Enterprise and Street Trading: a civil society and urban management perspective. In Alison Brown (Org.), Contested space: street trading, public space and livelihoods in Developing Cities (pp. 37-53). Warwick: ITDG Publishing.

Puplampu, Bill (2003). The 'neglected professions'- why don't we study Taxi Drivers, Waiters, Farmers, Street Sweepers and.... The Ocupational Psychologist, 48, 3-9.

Rakodi, Carole \& Lloyd-Jones, Tony. (2002). Urban Livelihoods: a people-centered approach to reducing poverty. London: Earthscan Publications.

Rodrigues, Adriana Agnes M. (2008). Os sentidos do auto-emprego nos pequenos negócios familiares geradores de renda. Unpublished master's thesis, Pontifícia Universidade Católica de São Paulo.

Sato, Leny (2007). Processos Cotidianos de Organização do trabalho na Feira Livre. Psicologia e Sociedade, 19 (Edição Especial 1), 95-102.

Sennet, Richard (1998). The Corrosion of Character: The Personal Consequences of Work in the New Capitalism. New York: W.W. Norton \& Company. 
De Soto, Hernando (2003). The mystery of capital: why capitalism triumphs in the West and fails everywhere else. New York: Basic Books.

Spink, Peter (2001). On Houses, Villages and Knowledges. Organization, 8(2), 219-226.

Spink, Peter (2007). Equity and Public Action. Harvard Review of Latin America, VI, 33-35.

Spink, Peter (2009a). Los psicologos y las políticas pública en america Latina: el Big Mac y Los Caballos de Troia. Psicoperspectivas, 8(2), 12-34.

Spink, Peter (2009b). Micro cadeias produtivas e a nano-economia: repensando o trabalho decente. Cadernos de Psicologia Social do Trabalho, 12(2), 227-242.

Suplicy, Eduardo M. (2006). Renda Básica de Cidadania: a resposta dada pelo vento. Porto Alegre: L\&PM.

Thompson, Edward P. (1993). Customs in Common. New York : New Press.

Thomas, Jim (1995). Surviving in the City. London: Pluto Press.

Tipple, Graham; Coulson Justine \& Kellet, Peter (2002). The effects of home-based enterprises on the residential environment in developing countries. In Sam Romaya \& Carole Radoki (Eds.), Building Sustainable Urban Settlements: approaches and case studies in the developing world (pp. 62-76). London: ITDG Publishing.

Wallman, Sandra (1982). Living in South London: perspectives on Battersea 1871-1981. Aldershot: Gower.

\section{Historia editorial}

Recibido: 03/10/2011

Aceptado: 15/10/2011

\section{Formato de citación}

Spink, Peter (2011). Whatever happened to Work: from the centrality of shoes, ships and sealing-wax to the problems posed by flying pigs. Athenea Digital, 11(3), 3-24. Disponible en http://psicologiasocial.uab.es/athenea/index.php/atheneaDigital/article/view/955 


\section{SORERIGHIS RESERVED}

Este texto está protegido por una licencia Creative Commons.

Usted es libre de copiar, distribuir y comunicar públicamente la obra bajo las siguientes condiciones:

Reconocimiento: Debe reconocer y citar al autor original.

No comercial. No puede utilizar esta obra para fines comerciales.

Sin obras derivadas. No se puede alterar, transformar, o generar una obra derivada a partir de esta obra.

Resumen de licencia - Texto completo de la licencia 